\section{PODOPOST SAMEN ONLINE}

\section{Social media valkuilen}

Social media-expert Maaike Gulden van The Marketing Factory vertelt over de valkuilen van social media. Belangrijk is vooral dat je vooraf bedenkt wat je doel is om op Facebook, Instagram of YouTube te gaan met je bedrijf. Op de website van Podopost ook 5 extra tips over social media.
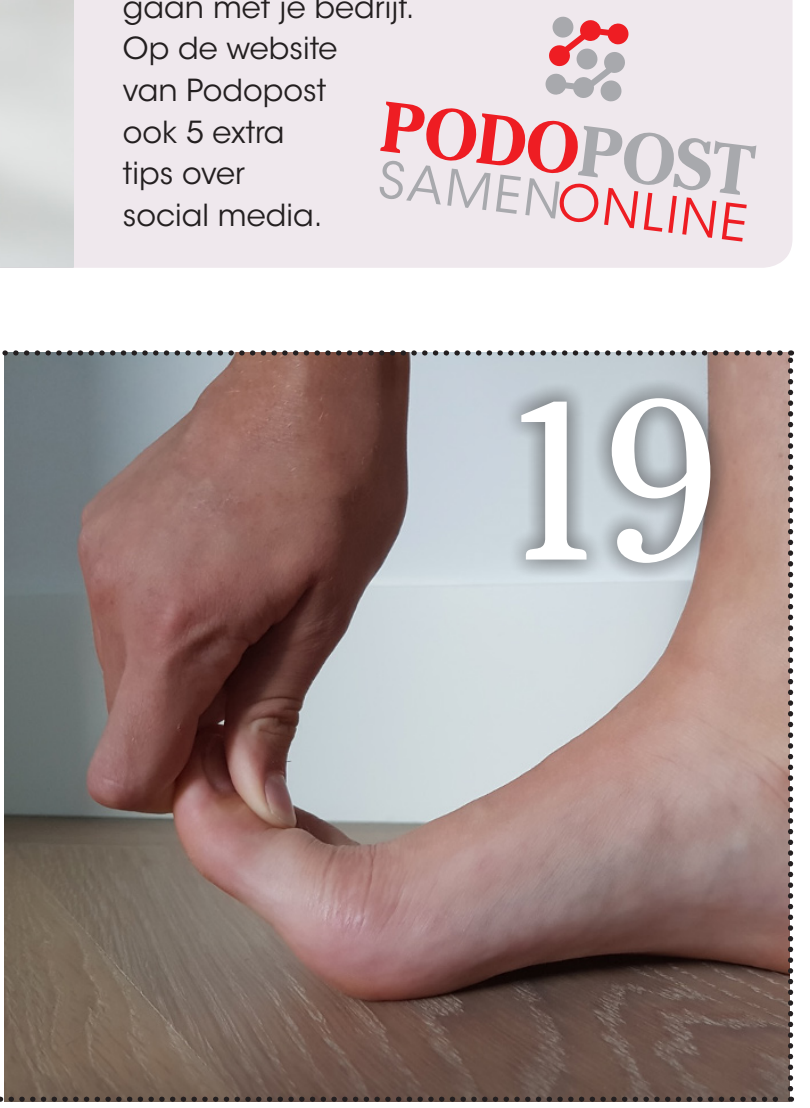

En verder

Vaknieuws

Column Bernadet

Voetenwerk

Podopost Samen Online-actie

Column Tineke de Beer

Ondernemen: pionieren in sport

Klanttevredenheid

Vakbeurs Pedicure exposantenoverzicht

Servicepagina en colofon

\section{Podopost Samen Online 2 PODOPOSTT
SAMENONLINE}

I n september hebben wij op kantoor van de uitgeverij pedicures uitgenodigd voor onze klankbordgroep. Samen hebben we gekeken naar wat ze van de artikelen van het afgelopen jaar vonden, wat huidige ontwikkelingen zijn en aan welke informatie behoefte is voor het komende jaar. Begin dit jaar zijn we gestart met de actie Podopost Samen Online, waarbij we in iedere uitgave in een extra ondernemersrubriek aandacht besteden aan een online thema voor de pedicurepraktijk. Daarbij plaatsen we extra informatie (een artikel, filmpje, training, peiling, relevante archiefartikelen) op onze website: www.podopost.nl, niet alleen bij de ondernemersrubriek, maar ook bij andere artikelen uit het tijdschrift. Tijdens de klankbordgroep bleek dat dit onvoldoende bekend is. Daarom breng ik het graag nog eens onder jullie aandacht. Bij artikelen waar het grijze blokje uit het Podopost Samen Online logo staat kun je voor aanvullende informatie naar de website. Via het Podopost Samen Online logo op de homepage kom je rechtstreeks uit op een aparte pagina (middels het adres www.podopost.nl/podopost-samen-online kun je er ook direct naar toe) waar we per uitgave laten zien wat er aan extra informatie is. Het plaatsen van extra informatie op de website zullen we stap voor stap uitbreiden.

En dan een ander onderwerp: het weekend van 27 en 28 oktober kun je ons vinden op de Vakbeurs Pedicure in stand 77. Op zaterdag is Johan Toonstra te gast in onze stand. Van 12.00-13.00 uur signeert hij zijn boeken. Daarnaast houden we als standhouder ook een korte Podopost-sessie van 20 minuten over de samenwerking in de diabetische voetzorg. Dit doen we samen met medisch pedicure Jeannet Schuurman, podotherapeut Sabine Scheepens en Margreet van Putten. Deze sessies zijn op beide dagen om 14.30-14.50 uur. De sprekers zijn daarna op de stand aanwezig om vragen uit de sessie te beantwoorden.

Ik ontmoet jullie graag.

Maureen Limpens, hoofdredacteur m.limpens@bsl.nl

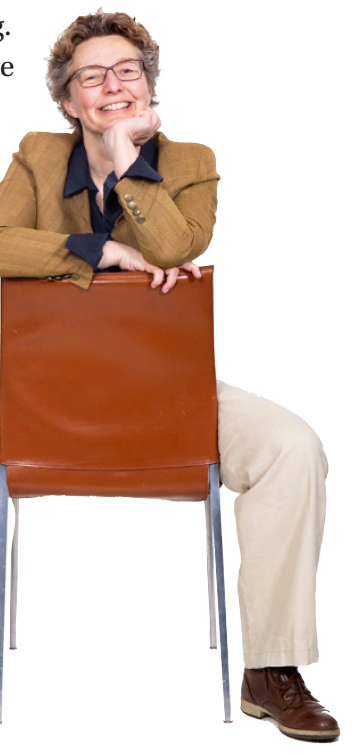

